\title{
Efektifitas Pemberian Tablet Fe dan Buah Pisang Ambon Dalam Meningkatkan Kadar Hemoglobin
}

\author{
Erni Muslikah ${ }^{1}$, Sulastri ${ }^{2 *}$
}

1Universitas Muhammadiyah Surakarta, Surakarta 57162, Jawa Tengah, Indonesia ${ }^{2}$ Departemen Keperawatan Maternitas, Universitas Muhammadiyah Surakarta, Surakarta 57162, Jawa Tengah, Indonesia.

* Korespodensi: sulastri@ums.ac.id

\begin{abstract}
Abstrak: Upaya penanggulangan anemia dapat dilakukan dengan pemberian tablet besi yang mengandung 30-60 mg zat besi dan $400 \mathrm{mg}$ asam folat. Buah pisang ambon mengandung zat besi, vitamin B6, dan vitamin C yang dapat memberikan manfaat antioksidan dalam meningkatkan sistem imunitas dan membantu memaksimalkan penyerapan zat besi. Penelitian ini bertujuan untuk mengetahui efektifitas tablet Fe dan buah pisang ambon dengan tablet Fe dalam meningkatkan kadar hemoglobin. Jenis penelitian ini adalah kuasi eksperimen semu pretest - posttest two group design. Jumlah sampel sebanyak 30 responden. Pembagian sampel yaitu 15 responden diberikan tablet Fe dan buah pisang ambon dan 15 responden hanya diberikan tablet Fe. Hasil penelitian ini uji Paired Sample T-Test, nilai signifikansi atau p-value dari tablet Fe dan buah pisang ambon sebesar 0.000, dengan nilai rata-rata $\mathrm{Hb}$ pre-test $10,540 \mathrm{~g} / \mathrm{dl}$ dan post-test 13,840 $\mathrm{g} / \mathrm{dl}$ atau mengalami peningkatan sebesar 3,3 g/dl dan nilai signifikansi atau p-value dari tablet Fe sebesar 0.000 , dengan nilai rata-rata Hb pre-test 11,060 $\mathrm{g} / \mathrm{dl}$ dan post-test 12,267 $\mathrm{g} / \mathrm{dl}$ atau mengalami peningkatan sebesar 1,2 g/dl. Kesimpulan penelitian ini menunjukkan adanya perbedaan kenaikan kadar hemoglobin yang signifikan antara kelompok tablet Fe dan buah pisang ambon dengan kelompok tablet Fe.
\end{abstract}

Kata Kunci: Tablet Fe, Buah Pisang Ambon, Kadar Hemoglobin, Anemia

Abstract: Abstract: An effort to overcome anemia can be done by administering iron tablets containing 30-60 $\mathrm{mg}$ of iron and $400 \mathrm{mg}$ of folic acid. Ambon bananas contain iron, vitamin B6, and vitamin $C$ which can provide antioxidant benefits in enhancing the immune system and help maximize iron absorption. This study aims to determine the effectiveness of Fe tablets and ambon bananas with Fe tablets in increasing hemoglobin levels. This type of research is a quasi quasi-pretest-posttest two group design experiment. The number of samples is 30 respondents. The distribution of the sample is 15 respondents given Fe tablets and ambon bananas and 15 respondents only given Fe tablets. The results of this study Paired Sample T-Test, the significance value or pvalue of Fe tablets and ambon bananas amounted to 0.000, with an average Hb pre-test $10.540 \mathrm{~g} / \mathrm{dl}$ and posttest $13.840 \mathrm{~g} / \mathrm{dl}$ or an increase of $3.3 \mathrm{~g} / \mathrm{dl}$ and the significance value or p-value of Fe tablets of 0.000, with an average $\mathrm{Hb}$ pre-test $11,060 \mathrm{~g} / \mathrm{dl}$ and post-test $12.267 \mathrm{~g} / \mathrm{dl}$ or an increase of $1.2 \mathrm{~g} / \mathrm{dl}$. The conclusion of this study showed that there was a significant difference in the increase in hemoglobin levels between the Fe tablet and ambon banana groups and the Fe tablet group.

Keywords: Fe tablet, Ambon banana, hemoglobin level, anemia 


\section{PENDAHULUAN}

Anemia merupakan masalah gizi utama yang terjadi di seluruh dunia. Prevalensi anemia di Asia pada wanita usia 15-45 tahun mencapai 191 juta orang, dan Indonesia menempati urutan ke 8 dari 11 Negara di Asia setelah Srilangka yaitu 7,5 juta orang dengan rata-rat usia 10-19 tahun (WHO, 2011). Remaja putri pada usia 15-24 tahun yang mengalami anemia sebesar 18,4\% (Riskesdas, 2013). Sedangkan pada usia 11- 14 tahun sebesar 2,8\%, dan usia 15-19 tahun sebesar 7,2\% (Soetjiningsih, 2010).

Pertumbuhan dan penambahan berat badan yang sangat cepat serta kehilangan zat besi pada saat menstruasi (12,5 mg atau 0,4-0,5 mg) menyebabkan remaja putri rentan terhadap anemia (WHO, 2011). Dampak yang sering muncul pada penderita anemia adalah mudah lelah, kurang tenaga atau lemas, dan kurang konsentrasi. Kekurangan zat besi dapat mempengaruhi derajat kesehatan, kemampuan saat belajar dan perkembangan otak anak remaja (Soetjiningsih, 2010).

Upaya penanggulangan anemia gizi besi dapat dilakukan dengan pemberian tablet besi yang mengandung 30-60 mg zat besi dan $400 \mathrm{mg}$ asam folat (WHO, 2016). Pemberian tablet besi dua kali perminggu selama dua bulan dapat meningkatkan kadar hemoglobin sebesar 0,99 g/dl (Ariutami, 2012). Hemoglobin merupakan suatu unsur protein majemuk yang mengandung unsur non-protein yaitu heme. Sintesis heme dalam memproduksi hemoglobin dibantu oleh piridoksin atau vitamin B6. Vitamin B6 dapat dijumpai pada daging dan buah-buahan. Buah pisang merupakan salah satu buah yang memiliki kandungan vitamin B6 yang cukup sebesar (Muchtadi, 2009). Pada 100 gram saji pisang ambon (1 buah) menggandung 73,8 g air, zat besi 0,5 mg, vitamin C 9 mg, B1 0,05 mg, B2 0,8 mg, B6 0,1 $\mathrm{mg}$ dan fosfor $28 \mathrm{mg}$ selain itu buah pisang ambon memiliki tekstrur yang lembut dan memiliki rasa yang manis (Antara, 2013).

\section{METODE}

Metode penelitian ini menggunakan eksperimen semu (Quasi-Experimental) dengan rancangan pretest-posttes two group design. Sampel berjumlah 30 siswi yang mengalami anemia di SMA 1 Nguter Kabupaten Sukoharjo, kemudian sampel dibagi dalam dua kelompok yaitu 15 kelompok perlakuan tablet Fe dan buah pisang ambon (Musa Paradisiaca Var. Sapientum (L) Kunt) dan 15 kelompok perlakuan tablet $\mathrm{Fe}$ (variabel independent), peningkatan kadar hemoglobin (variabel dependent). Pengumpulan data dilakukan dengan mengambil sampel darah kapiler yang kemudian diukur kadar hemoglobin sebelum dan setelah pemberian perlakuan pada kedua kelompok (kelompok tablet Fe dan buah pisang ambon dengan kelompok tablet $\mathrm{Fe}$ ) dengan menggunakan alat pengukur kadar hemoglobin QuikCheck. Kemudian dilakukan pengolahan data, analisis univariat dan analisis bivariat.

\section{HASIL}

Grafik 1 Distribusi responden berdasarkan umur

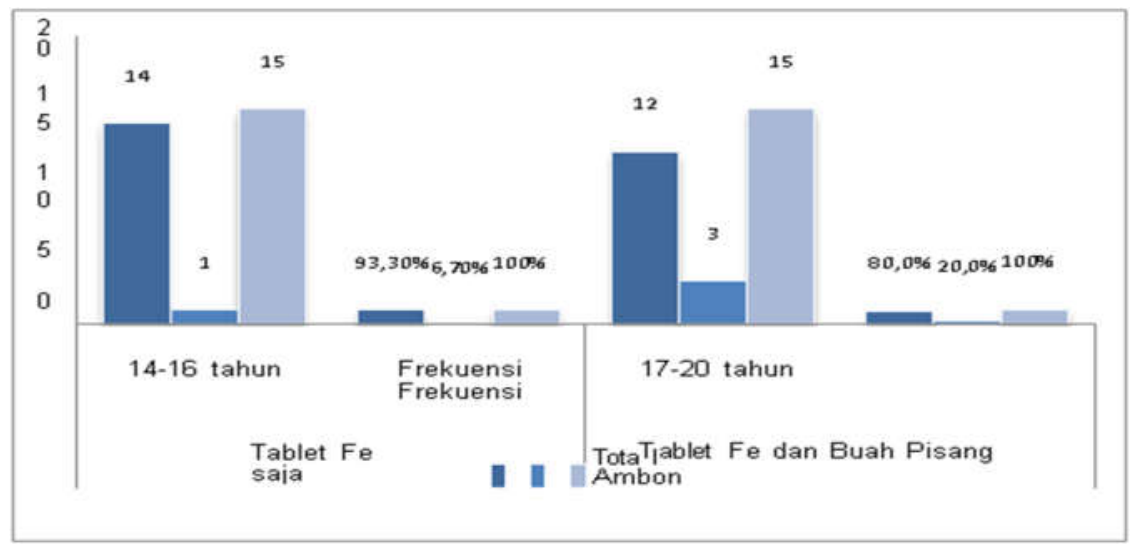


Berdasarkan distribusi data di atas, rata-rata umur responden pada kelompok tablet Fe yaitu 14-16 tahun sebanyak 14 (93,3\%) orang, dan yang berusia 17-20 terdapat 1 (6,7\%) orang. Sedangkan pada kelompok tablet Fe dan buah pisang ambon usia 14-16 tahun sebanyak 12 (80,0\%) orang, dan yang berusia 17-20 tahun sebanyak $3(20,0 \%)$ orang.

Grafik 2. Distribusi kadar hemoglobin sebelum diberikan perlakuan

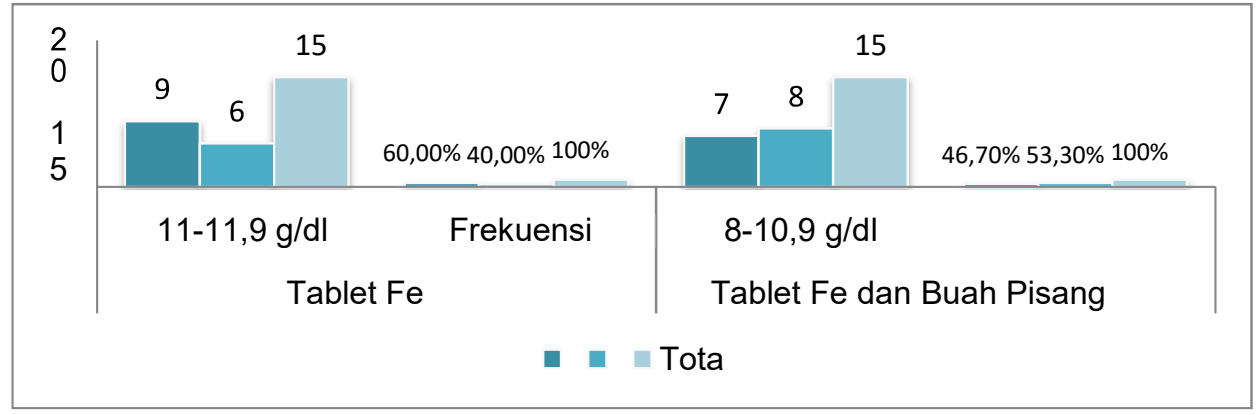

Hasil distribusi data diatas menunjukkan kelompok intervensi tablet Fe yang mengalami anemia ringan sebanyak 9 orang $(60,0 \%)$ dan anemia sedang sebanyak 6 orang (40,0\%). Sedangkan kelompok intervensi tablet Fe dan buah pisang ambon yang mengalami anemia ringan sebanyak 7 orang $(46,7 \%)$ dan sebanyak 8 orang $(53,3 \%)$ anemia sedang..

Grafik 3 Distribusi kadar hemoglobin setelah diberikan perlakuan

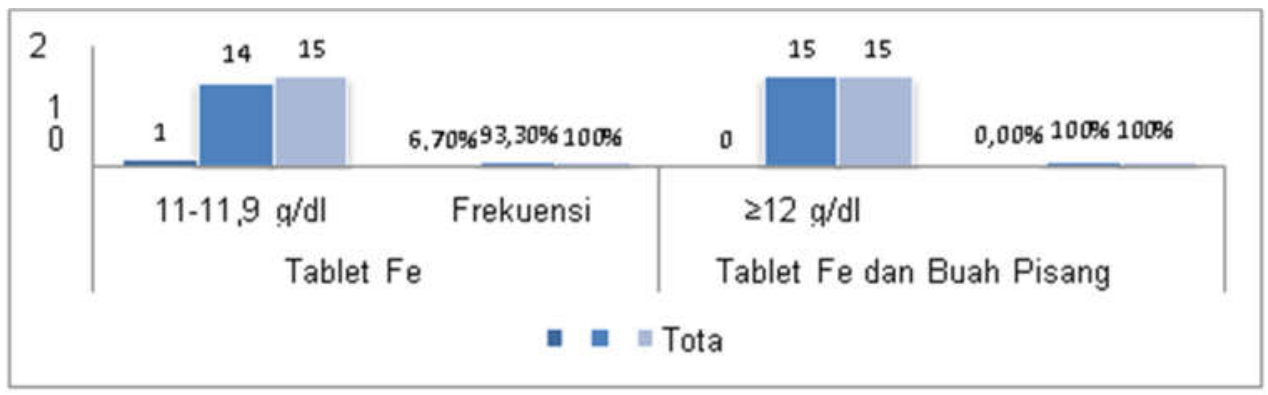

Hasil distribusi data diatas menunjukkan adanya perubahan peninggakatan kadar hemoglobin pada kedua kelompok. Pada kelompok yang hanya diberikan tablet Fe 14 responden (93,3\%) mengalami peningkatan kadar hemoglobin yaitu $\geq 12 \mathrm{~g} / \mathrm{dl}$ dan 1 responden $(6,7 \%)$ masih mengalami anemia ringan. Sedangkan pada kelompok yang diberikan tablet Fe dan buah pisang ambon, sebanyak 15 responden $(100,0 \%)$ mengalami peningkatan kadar hemoglobin yaitu $\geq 12 \mathrm{~g} / \mathrm{dl}$.

Grafik 4 Perbedaan kadar hemoglobin sebelum dan setelah pemberian tablet Fe saja dengan tablet Fe dan buah pisang ambon (Musa Paradisiaca Var. Sapientum (L) Kunt)

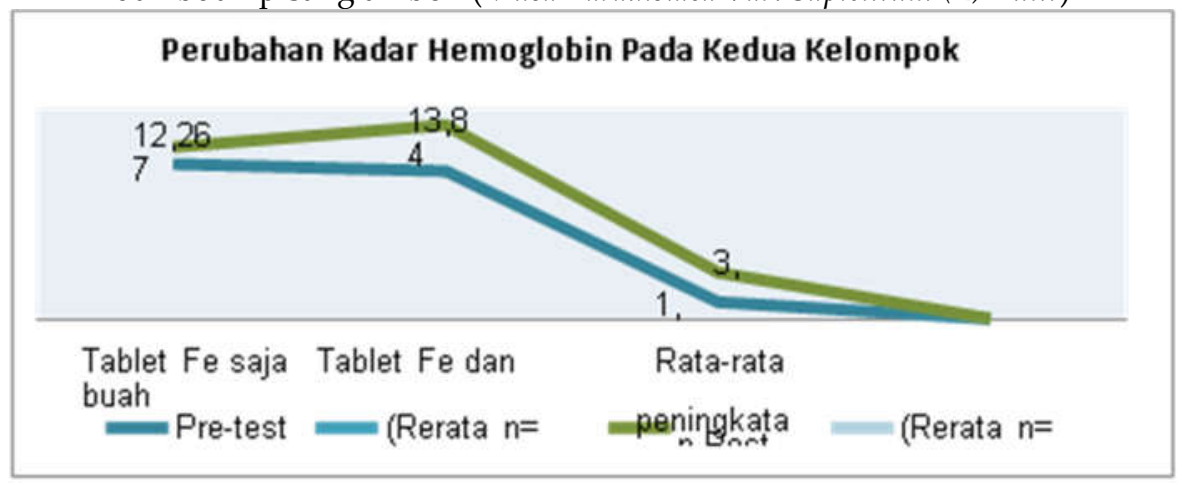


Berdasarkan hasil Uji Paired Sampel Test di atas, diperoleh peningkatan kadar hemoglobin setelah pemberian perlakuan pada kelompok yang hanya diberikan tablet Fe sebesar 1,2 g/dl $(t=-7.924, p=$ 0,000). Sedangkan pada kelompok yang diberikan tablet Fe dan buah pisang ambon (Musa Paradisiaca Var. Sapientum (L) Kunt) sebesar 3,3 g/dl ( $t=-10.829, p=0,000)$.

Tabel 1. Perbandingan kadar hemoglobin sebelum dan setelah pemberian tablet Fe saja dengan tablet Fe dan buah pisang ambon (Musa Paradisiaca Var. Sapientum (L) Kunt)

\begin{tabular}{llllll}
\hline Kelompok Perlakuan & \multicolumn{2}{l}{$\begin{array}{l}\text { Kadar hemoglobin } \\
\text { (g/dl) }\end{array}$} & \multicolumn{2}{l}{ Kesimpulan } \\
\cline { 2 - 4 } & \multicolumn{2}{c}{$T$} & \\
\hline $\begin{array}{l}\text { Kelompok tablet Fe sajaPre-test } \\
\text { dengan kelompok tablet Fe }\end{array}$ & 1,793 & 0,84 & H0 diterima \\
\cline { 2 - 3 } dan buah pisang ambon & Post-test & 7,171 & 0,000 & H0 ditolak
\end{tabular}

Hasil uji Independent Sample T-Test pada kedua kelompok sebelum diberikan perlakuan menunjukkan nilai signifikansi atau $p$-value $\geq 0,05(0,84 \geq 0,05)$. Sedangkan hasil pada kedua kelompok setelah diberikan perlakuan menunjukkan nilai $p$-value $\leq 0,05(0.000 \leq 0,05)$

\section{PEMBAHASAN}

\section{Distribusi Frekuensi Responden Berdasarkan Umur}

Responden dalam penelitian ini adalah siswi putri yang sebagian besar berusia 14-16 tahun. Pada usia ini, terjadi pertumbuhan yang sangat cepat sehingga kebutuhan akan gizi dan zat besi relatif meningkat (Proverawati, 2011). Selain itu, kehilangan darah pada saat menstruasi merupakan faktor penyebab kurang besi pada anak perempuan sehingga anak perempuan lebih rentan terhadap anemia (WHO, 2011). Hasil penelitian terdahulu menunjukkan sekitar 38,0\% anak yang berada pada usia $12-$ 17 tahun rentan mengalami anemia (Leenstra, et al., 2006).

\section{Nilai Kadar Hemoglobin Sebelum Diberikan Perlakuan}

Hasil penelitian menunjukkan nilai kadar hemoglobin sebelum diberikan perlakuan sebesar 8$11,9 \mathrm{~g} / \mathrm{dl}$. Hal ini dikarenakan kebutuhan fisiologis yang meningkat, kurangnya asupan besi dari makanan dan terjadinya malabsorbsi zat besi. jika keseimbangan besi yang negatif ini menetap akan menyebabkan cadangan besi terus berkurang (Permono, 2012). Sehingga tubuh membutuhkan preparat besi dan vitamin untuk mengganti kekurangan besi dalam tubuh (Bakta, 2015).

\section{Tablet Fe Dalam Meningkatkan Kadar Hemoglobin Siswi Anemia}

Pada grafik 3 menunjukkan adanya kenaikan kadar hemoglobin sebesar 1,2 g/dl setelah pemberian tablet Fe yang mengandung $300 \mathrm{mg}$ zat besi dan $2 \mathrm{mg}$ asam folat yang diberikan pada siswi anemia dua kali perminggu selama 28 hari. Hasil penelitian terdahulu menunjukkan adanya peningkatan kadar hemoglobin sebesar 0,96 g/dl setelah diberikan suplemen besi dua kali perminggu selama tiga minggu (Hawamdeh, et al., 2013). Pemberian suplemen besi yang mengandung 30-60 mg zat besi dan $400 \mathrm{mg}$ asam folat dapat meningkatkan kadar hemoglobin (WHO, 2011). Selain itu, tablet besi yang diberikan pada remaja putri dalam bentuk besi (II) fumarat penyerapanya 3 kali lebih baik dibandingkan garam feri (Permono, 2012).

\section{Tablet Fe Dan Buah Pisang Ambon (Musa Paradisiaca Var. Sapientum (L) Kunt) Dalam Meningkatkan Kadar Hemoglobin Siswi Anemi}

Pada grafik 3 menunjukkan adanya peningkatan kadar hemoglobin sebesar 3,3 g/dl setelah pemberian tablet Fe yang mengandung $300 \mathrm{mg}$ zat besi, $2 \mathrm{mg}$ asam folat dan 1 buah (100 gram) pisang ambon yang diberikan pada siswi anemia dua kali perminggu selama 28 hari. Untuk memaksimalkan penyerapan zat besi maka harus diberikan bersamaan dengan sumber makanan yang mengandung vitamin $\mathrm{C}$ misalnya buah pisang ambon. Kandungan vitamin B6 dan vitamin $\mathrm{C}$ dan zat besi pada buah 
pisang ambon dapat membantu memproduksi antibodi, metabolisme lemak, sel-sel darah merah, serta menstimulasi produksi hemoglobin dalam darah pada penderita anemia (Kumar, et al., 2012). Hasil penelitian terdahulu menyatakan bahwa penyerapan zat besi total pada 100 gram pisang matang adalah 0,86 mg (Garcia, et al., 2015). Besi nonheme yang terdapat dalam pisang ambon ketika berada dalam lambung akan diabsorpsi oleh vitamin C (9 mg). didalam lambung akan terjadi perubahan besi feri menjadi fero sehingga mudah diserap oleh tubuh. Dalam sirkulasi darah akan diikat menjadi transferin selanjutnya akan bersenyawa dengan profirin membentuk heme, selanjutnya heme akan bersenyawa dengan globulin dan membentuk hemoglobin (Bakta, 2015).

\section{Perbandingan Keefektifan Kedua Kelompok Intervensi}

Berdasarkan tabel 5 menunjukkan bahwa kelompok yang diberikan tablet Fe dan buah pisang ambon lebih efektif dibandingkan dengan kelompok yang hanya diberikan tablet Fe dalam meningkatkan kadar hemoglobin siswi anemia di SMA 1 Nguter Kabupaten Sukoharjo yaitu 1,2 g/dl pada kelompok tablet Fe dan 3,3 g/dl pada kelompok tablet Fe dan buah pisang ambon. Buah pisang ambon mengandung vitamin B6, vitamin C dan zat besi yang dapat membantu penyerapan zat besi dengan cepat karena mampu mengubah besi feri menjadi fero yang siap diserap oleh tubuh (Bakta, 2015).

\section{KESIMPULAN}

Kedua kelompok intervensi efektif dalam meningkatkan kadar hemoglobin siswi anemia di SMA 1 Nguter dengan nilai signifikansi $(0.000 \leq 0.05)$. Hasil uji t independen menunjukkan kelompok yang diberikan tablet Fe dan buah pisang ambon (Musa Paradisiaca Var. Sapientum (L) Kunt) dalam hal ini lebih efektif dalam meningkatkan kadar hemoglobin pada siswi anemia dengan selisih sebesar 2,3 g/dl. Sebagai bahan informasi atau sumber pengetahuan tentang manfaat mengkonsumsi tablet Fe dan buah pisang ambon yang dapat mempercepat kenaikan kadar hemoglobin pada penderita anemia, dibandingkan hanya mengkonsumsi tablet Fe saja. Hasil penelitian ini dapat menjadi acuan bagi peneliti berikutnya.

\section{DAFTAR PUSTAKA}

Antara, M., \& Wirawan, I. (2013). Permintaan Buah Pisang Ambon Oleh Rumah Tangga di Kecamatan Denpasar Barat, Kota Denpasar, Provinsi Bali. Jurnal Ekonomi Kuantitatif Terapan, 6(1).

Ariutami, RK., Subagio HW, 2012. Beda Kadar Hemoglobin Remaja Putri Anemia Setelah Pemberian Suplementasi Tablet Besi Folat Satu Kali Dan Dua Kali Per Minggu. Diakses dari website: http://eprints.undip.ac.id/35951/1/429_Kintha_Raditya_Ariutami_G2C007041. pdf. Pada tanggal 29 Agustus 2016.

Hawamdeh, H.M., Rawashdeh, M., Aughsteen, AA, 2013. Comparison Between Once Weekly, Twice Weekly, And Daily Oral Iron Therapy In Jordanian Children Suffering From Iron Deficiency Anemia. Journal Matern Child Health 17:368-373 DOI 10.1007/s10995-012-0981-3

Kementrian Kesehatan RI. 2015. Pedoman Program Pemberian Pemantauan Mutu Tablet Tambah Darah Untuk Ibu Hamial. Jakarta: Challenge Corporation

Kumar, kps., bhowmik, d., duraivel, s., umadevi, m,. (2012). Traditional and medicinal uses of banana. Journal of pharmacognosy and phytochemistry, no: 8192.

Leenstra, T., Acosta, L. P., Langdon, G. C., Manalo, D. L., Su, L., Olveda, R. M., ... \& Friedman, J. F. (2006). Schistosomiasis japonica, anemia, and iron status in children, adolescents, and young adults in Leyte, Philippines. The American journal of clinical nutrition, 83(2), 371-379.

Muchtadi, D. 2009, Gizi Anti Penuaan Dini. Bandung: Afabeta.

Norsiah, W. 2015. Perbedaan kadar hemoglobin metode sianmethemoglobin dengan dan tanpa sentrifugasi pada sampel leukositosis. Journal medical laboratory technology. Available online at : http//ejurnal-analisiskesehatan.web.id. 2461-0879

Notoatmodjo, S, 2012. Metodologi Penelitian Kesehatan. Jakarta: Rineka Cipta.

Proverawati, A., dan Wati, E K. (2011). Ilmu Gizi Untuk Keperawatan dan Gizi Kesehatan. Yogyakarta: 
Nuha medika.

Permono, H.B., Sutaryo., Ugrasena, IDG., Windiastuti, E., Abdulsalam, M. (2012). Buku ajar hematologi onkologi anak. Jakarta: IDAI

Riset kesehatan dasar (Riskesdas), 2013. Pedoman Pewawancara Petugas Pengumpul Data. Jakarta: badan litbangkes.

Renstra, 2015. Rencana Strategi Kementrian Kesehatan Tahun 2015-2016. Jakarta: Kementrian Kesehatan RI.

Soetjiningsih, 2010. Tumbuh Kembang Remaja Dan Permasalahnya. Jakarta: CV Sagung Seto.

Word Health Organization, (2011a). Guideline: intermittent iron and folic acid supplementation in menstruating women.978 9241502023 